\title{
Corona Makes Me a Procrastinator: Correlates Personality in Predicting Procrastination
}

\author{
Thoyyibatus Sarirah ${ }^{1}$ \\ \{thoyyibatus@ub.ac.id $\left.{ }^{1}\right\}$ \\ Department of Psychology, Brawijaya University, Indonesia ${ }^{1}$
}

\begin{abstract}
The emergence of the coronavirus or covid-19 caused shocks throughout the world, both from a social, economic, and educational perspective. One way to avoid the spread of covid-19 was by implementing school for home. Procrastination can occur in students who underwent school at home because the control of the learning environment and teacher control was lacking. For this reason, the role of personality supported in predicting whether students will procrastinate during school for home. The purpose of this study was to determine the role of personality in procrastination. 174 respondents (40 men and 134 women) who were currently undergoing school at home were used in this study. The instruments used were the Uni Procastination Scale and the Big Five Inventory. Data analysis used multiple regression. Respondents who admitted to procrastination after undergoing school at home were only $\mathrm{M}=10.6$. The results of the data analysis did not support the research hypothesis, which showed that there was no personality role for procrastination. the role of social support, especially parents, student motivation, and selfregulated learning to consider when students underwent school for home.
\end{abstract}

Keywords: Corona, procrastination, personality

\section{Introduction}

Since the Covid-19 pandemic, the whole world had been affected. To avoid the spread of Covid-19, all kinds of methods were used, either by locking down, Large-Scale Social Restrictions (PSBB), or Local-Scale Social Restrictions. The government also urged the public to carry out physical distancing, both in offices, government agencies, and others. In the world of education, especially at this time, there was still a school for home (SFH) where students learned online. Students who did online learning were found to experience psychological problems in the form of stress, anxiety to mild depression [4]. If it was in weekly times. Procrastination resulted in negative emotions [1], psychological distress [3] dan low psychological well-being [13].

Procrastination caused by internal factors, one of the determining factors is personality. Many studies showed that personality predicted personality [6][15]. Kim et al [7] studied 178 students whose results found that personality extraversion and neuroticism were associated with procrastination. Sarirah and Rahayu [14] found the opposite where personality extraversion, agreeableness, and conscientiousness were associated with procrastination.

Personality related to anxiety and depression when facing Covid-19 pandemic. where people with extraversion, agreeableness, and openness tend to have low anxiety and depression, whereas people who had neurotic personalities tend to be prone to anxiety and depression [11]. 
In learning, the use of different learning strategies depended on the personality they had where people with Extraversion and Neuroticism personalities tend to use strategies in learning, while different results were seen in personality conscientiousness, openness to experience, and agreeableness [8]. Personality was related to hardiness where neurotic people had low hardiness scores, while other personalities had high hardiness scores [17].

\section{Method}

\subsection{Research design}

174 respondents (40 men and 134 women) were used in the study. The selected respondents are students who were currently underwent school for home. Researchers distributed questionnaires in the form of google. form and distributed to student groups and on social media.

\subsection{Instruments}

\subsubsection{Uni procrastination scale (UPS)}

Setiawan [16] developed a procrastination scale called the Uni Procrastination Scale (UPS). This scale was based on the Irrational Procrastination Scale (IPS) and the Procrastination Cognitive Inventory (PCI). There were 5 items on this scale using a Likert scale. Examples of items on the "I'm a procrastinator, I can't get to my goal" scale.

\subsubsection{Big five inventory (BFI)}

This study used the BFI scale that had been adapted by Sarirah dan Rahayu [14]. There were five personality factors, namely extraversion, agreeableness, conscientiousness, neuroticism, openness to experience. Big Five Personality (BFI) consisted of 44 items using a Likert scale.

\subsection{Data analysis technique}

To test the hypothesis in this study, researchers used multiple regression data analysis techniques, because in this study, personality variables couldn't be measured singly. There were 5 personality factors (extraversion, agreeableness, conscientiousness, neuroticism, openness to experience) that were associated with procrastination. Data analysis used JASP version 0.13.1 software.

\section{Result and Discussion}

\subsection{Results}

Researchers distributed online questionnaires and got 174 subjects. Following were the results of the description of the variables $\mathrm{X}$ (personality) and Y (procrastination). 
Table 1. Variable Description

\begin{tabular}{lll}
\hline & Mean & SD \\
\hline Procrastination & 10.615 & 2.111 \\
Extraversion & 18.103 & 3.409 \\
Agreeableness & 24.534 & 2.866 \\
Conscientiousness & 23.494 & 3.425 \\
Neuroticism & 23.034 & 3.695 \\
Openness to Experience & 28.213 & 3.289 \\
\hline
\end{tabular}

Based on Table 1, it showed that the majority of subjects had openness to experience with a mean of 28,213 and the lowest was extraversion with a mean of 18,103 . the majority of subjects also admitted to procrastination with a mean of 10,615

Table 2. Hypothesis Test

\begin{tabular}{lccccc}
\hline \multicolumn{1}{c}{ Variable } & $\boldsymbol{R}$ & & $\boldsymbol{F}$ & RMSE & $\boldsymbol{p}$ \\
\hline $\begin{array}{l}\text { Procrastination } \\
\text { *Personality }\end{array}$ & .109 & .404 & 2.130 & .845 & \\
\hline
\end{tabular}

Table 3. Results of Multiple Resgression

\begin{tabular}{lllll}
\hline \multicolumn{1}{c}{ Variable } & SE & & $\mathbf{t}$ & \multicolumn{1}{c}{$\mathbf{p}$} \\
\hline Extraversion & .053 & -.663 & .508 \\
Agreeableness & .061 & -.271 & .787 \\
Conscientiousness & .052 & -1.126 & .262 \\
Neuroticism & .050 & -.883 & .379 \\
Opennes to Experience & .052 & .471 & .638 \\
\hline
\end{tabular}

Based on Table 2 and Table 3, it was found that personality variables, both extraversion, agreeableness, conscientiousness, neuroticism, and openness to experience were unable to predict procrastination with F.404 ( $\mathrm{p}>.05$ ).

\subsection{Discussion}

The results of this study found that there was no role for personality towards procrastination in students who underwent school for home. The results of this study differ from the results of previous studies where personality can predict procrastination [6][7][14][15].

Zhou's study [18] that distinguished between active and passive procrastination found that extraversion was positively associated with active procrastination, whereas agreeableness was negatively associated with active procrastination. Lai [15] supported this finding where personality of any type did not predict procrastination. Rejecting the hypothesis in this study, the researcher assumed that very dramatic changes, both environmental, social, especially the learning model during the Covid-19 pandemic, which must be implemented online, causes all students to procrastinate regardless of personality aspects.

Social support was needed in pandemic conditions, how parents monitored their children when studying online at home. Social support and high self-efficacy prevented students from procrastinating their schoolwork [19]. Sari and Fakhruddiana [12] emphasized these findings, 
where the results of her research found that social support and internal locus of control were needed for someone to avoid procrastination.

Low motivation and self-esteem were predicted to increase procrastination. Someone who had a task-avoiding behavior was often seen procrastinating [2]. A procrastinator also had poor sleep quality [9]. Having less hours of sleep because of spending more time on behaviors that were pleasing to him than doing tasks. This online learning where the lack of control from the teacher during learning caused students to procrastinate. Hudaifah [5] strengthening the assumptions of researchers where in the results of his research he found that the self-regulated learning (SRL) affected students SFH SRL had a negative correlation with procrastination [10].

\section{Conclusion}

There is no role for personality (extraversion, agreeableness, conscientiousness, neuroticism, openness to experience) on procrastination. Suggestions for future researchers are expected to consider other variables, such as demographics, motivation, especially selfregulated learning of students who are running school at home.

\section{References}

[1] Chen, Z., Zhang, R., Xu, T., Yang, Y., Wang, J., \& Feng, T. (2020). Emotional attitudes towards procrastination in people: A large-scale sentiment-focused crawling analysis. Computers in Human Behavior, 110(2), 106391. https://doi.org/10.1016/j.chb.2020.106391

[2] Díaz-Morales, J. F., Cohen, J. R., \& Ferrari, J. R. (2008). An integrated view of personality styles related to avoidant procrastination. Personality and Individual Differences. https://doi.org/10.1016/j.paid.2008.06.018

[3] Eisenbeck, N., Carreno, D. F., \& Uclés-Juárez, R. (2019). From psychological distress to academic procrastination: Exploring the role of psychological inflexibility. Journal of Contextual Behavioral Science, 13(June), 103-108. https://doi.org/10.1016/j.jcbs.2019.07.007

[4] Hasanah, U., Ludiana, Immawati, \& PH, L. (2020). Gambaran Psikologis Mahasiswa Dalam Proses Pembelajaran Selama Pandemi Covid-19. Jurnal Keperawatan Jiwa, 8(3), 299-306. https://jurnal.unimus.ac.id/index.php/JKJ/article/view/5941

[5] Hudaifah, F. (2020). Peran Self Regulated Learning di Era Pandemi Covid-19. Jurnal Ilmiah Fakultas Keguruan Dan Ilmu Pendidikan, 6(2), 76-84.

[6] Karatas, H. (2015). Correlation among academic procrastination, personality traits, and academic achievement. Anthropologist, 20(1-2), 243-255.

[7] Kim, S., Fernandez, S., \& Terrier, L. (2017). Procrastination, personality traits, and academic performance: When active and passive procrastination tell a different story. Personality and Individual Differences, 108, 154-157. https://doi.org/10.1016/j.paid.2016.12.021

[8] Kokkinos, C. M., Kargiotidis, A., \& Markos, A. (2015). The relationship between learning and study strategies and big five personality traits among junior university student teachers. Learning and Individual Differences, 43, 39-47. https://doi.org/10.1016/j.lindif.2015.08.031

[9] Li, X., Buxton, O. M., Kim, Y., Haneuse, S., \& Kawachi, I. (2020). Do procrastinators get worse sleep? Cross-sectional study of US adolescents and young adults. SSM - Population Health, 10, 100518. https://doi.org/10.1016/j.ssmph.2019.100518

[10] Motie, H., Heidari, M., \& Sadeghi, M. A. (2012). Predicting Academic Procrastination during SelfRegulated Learning in Iranian first Grade High School Students. Procedia - Social and Behavioral Sciences, 69(Iceepsy 2012), 2299-2308. https://doi.org/10.1016/j.sbspro.2013.02.023 
[11] Nikčević, A. V., Marino, C., Kolubinski, D. C., Leach, D., \& Spada, M. M. (2020). Modelling the contribution of the Big Five personality traits, health anxiety, and COVID-19 psychological distress to generalised anxiety and depressive symptoms during the COVID-19 pandemic. Journal of Affective Disorders. https://doi.org/10.1016/j.jad.2020.10.053

[12] Sari, W. L., \& Fakhruddiana, F. (2019). Internal locus of control, social support and academic procrastination among students in completing the thesis. International Journal of Evaluation and Research in Education, 8(2), 363-368. https://doi.org/10.11591/ijere.v8i2.17043

[13] Sarirah, T. (2017). Apakah Prokrastinator Sejahtera Psikologisnya? Studi Pada Dosen Di Universitas $X$ Malang. INSAN Jurnal Psikologi Dan Kesehatan Mental, 1(2), 134. https://doi.org/10.20473/jpkm.v1i22016.134-140

[14] Sarirah, T., \& Rahayu, Y. P. (2019). The Relationship of Personality and Avoidance Procrastination Among University Students. Hasil Penelitian Jurnal Psibernetika, 12(1), 12-19. https://doi.org/10.30813/psibernetika.v12i1.1583

[15] Seong Lai, C. (2015). An Exploratory Study on Personality Traits and Procrastination Among University Students. American Journal of Applied Psychology, 4(3), 21. https://doi.org/10.11648/j.ajap.s.2015040301.14

[16] Setiawan, I. (2013). "If I Am Sure To Do That Now, ..." Penyusunan Uni Procrastination Scale. Calyptra, Jurnal Ilmiah Mahasiswa Universitas Surabaya, 2(1), 1-11.

[17] Zhang, L. fang. (2011). Hardiness and the Big Five personality traits among Chinese university students. Learning and Individual Differences, 21(1), 109-113. https://doi.org/10.1016/j.lindif.2010.05.006

[18] Zhou, M. (2019). The role of personality traits and need for cognition in active procrastination. Acta Psychologica, 199(July), 102883. https://doi.org/10.1016/j.actpsy.2019.102883

[19] Zubaidi, A. (2019). The Influence Of Self- Efficacy And Parent's Social Supports On Academic Procrastination Of Students. European Journal of Education Studies, 1997, 385-391. https://doi.org/10.5281/zenodo.3360238 